\title{
The Impact of Pay Level Satisfaction and Company Reputation on Work Engagement: A Study on Employees Graduated Between 2010 and 2017 working in Saudi Arabia Universities
}

\author{
Maha Saeed Alzailai \& Dr Soad A. Almeshal \\ King Saud University \\ E-mail: msalzailai@ksu.edu.sa
}

Received: March 14, 2019

Accepted: May 27, 2019

Published: July 1, 2019

doi:10.5296/jmr.v11i3.14940

URL: https://doi.org/10.5296/jmr.v11i3.14940

\begin{abstract}
Purpose: the main purpose of this study is to investigate and understand the impact of pay level satisfaction and company reputation on work engagement.

Design/methodology/approach: the study considered an empirical study that uses a qualitative method and probability sampling technique. The questionnaire was conduct using internetbased survey where the sample includes random male and female working in both public and privet Saudi universities with 72 retrieved.

Findings: the study shows that pay level satisfaction and company reputation have a significant statistical impact on work engagement.
\end{abstract}

Keywords: pay level satisfaction, company reputation, work engagement, Saudi Employee, Saudi Universities. 


\section{1) Macrothink}

Journal of Management Research

ISSN 1941-899X

2019, Vol. 11, No. 3

\section{Introduction}

Work engagement gets great attention from companies which have an impact on the outcomes of the company. Therefore, companies provide all means of attraction for the employees and provide an environment conducive to work, achievement and to gain competitive advantage. The company faces a challenge to maintain employees and motivate them to work. There are many factors that insure the work engagement within the company such as the level of pay which reflects the employee's satisfaction of work and commitment to the company. Other factors can affect work engagement and have a huge impact on employees; company reputation will be affected by the patent of its market activities and the stakeholders' image of the company.

As mentioned above work engagement is affected by both pay level satisfaction and company reputation. Therefore, due to the lack of research that links the impact of pay level satisfaction and company reputation to work engagement. The purpose of this research is to understand and examine the impact of pay level satisfaction and company reputation on work engagement on the employees in the industry of both public and private universities in Saudi Arabia from 2010 to 2017 .

\section{Research objectives}

The objectives of the current study are:

1- To measuring the impact of pay level satisfaction on work engagement.

2- To measuring the impact of company reputation on work engagement.

To explain the impact of the study variable (Pay level satisfaction and company reputation) on the work engagement.

\section{Literature review}

Varshney and Varshney (2017) noted that the government of Saudi Arabia over the past 10 years has aimed to apply the Saudization program in order to replace foreign workers with local Saudi ones. Saudi Arabia faces the shortage in skilled workers who are a big segment of the freshly graduates. The country worked hard to reorder their economy and to raise the human capital. The government goal was a future of knowledge-based economy, and was supported by the vision of the Saudi economy which is supposed to be achieved by 2024 . This leads them to build academic universities, technological innovation centers, research centers, and technological incubators.

A. Aboshaiqah (2016) noted that in 1992, Saudization of the workforce started to be applied by the Ministry of Labor, which is planned to replace the recruited foreign workforce from the kingdom by Saudi citizens. Additional, the Monarchy of Saudi Arabia issued that all firms in all areas and regardless of the number of workers, will work to attract and hire Saudis, offer good services to keep them on the job and provide them an opportunity to show their suitability for the job by managing, training and meeting the requirements for their jobs. 
A study by Alharbi, Wilson, Woods, and Usher (2016) among Saudi national and non-national nurses of burnout Saudi hospital found a high degree of burnout with a high rate of emotional tiredness and depersonalization, both are predictors of burnout. Burnout and job satisfaction are related together and leads to the other. Study was on nurses in Saudi hospital shows that there are links between burnout and other factors, including nurses' efficiency, emotional instability, a feeling of some degree of achievement and an unsolved urge to leave the job. The report concludes that a feeling of uncertainty and dissatisfaction with their jobs but were satisfied with the environment of their work. A. E. Aboshaiqah, Hamadi, Salem, and Zakari (2016) argued that in the nursing career, work engagement is important because of the lack of nurses and the continuing reduction in healthcare costs. Additionally, low levels of work engagement have been testified among nurses in comparison with other healthcare workers. The study shows significant changes in nurses' engagement among the several work settings and in nurses' age and experience

For 45 years the Saudi government has been trying to assess the efforts to diversify their economy through nine development plans. The successes to accomplish that relies on both investing in non- oil sectors and in the influence of private and public sectors. They also tried to improve the competition among companies and to attract the FDI to raise the efficiency of the Saudi market as discussed by Banafea and Ibnrubbian (2018). The objectives of the economic and social developmental strategy for Saudi Arabia are to maintain its religious and ethical values, and to increase the living standards and welfare of its individuals. Burton (2016) noted that the topic of Saudi Arabia's efforts to privatize its government enterprises and its approval to the World Trade Organization (WTO) offer further understanding into the combination of Saudi private business and the economic development aims of the nation. Additionally, entrepreneurship in Saudi Arabia is supported by the work of The Centennial Fund (TCF) and The Saudi Technology Development and Investment Companies, or TAQNIA the most famous Saudi company which combines technology with entrepreneurship.

To conclude, the majority of studies in Saudi Arabia explored the Saudization program, job satisfaction and work engagement of nurses in Saudi hospitals, government economy and business in Saudi Arabia. Thus, there is a need to research the impact of pay level satisfaction and company reputation, on work engagement in Saudi sectors in order to add value to this field by focusing on exploring the Saudi Arabian context.

\section{a) Pay level satisfaction}

Pay level satisfaction refers to the individuals who are satisfied with essential pay Ren, Fang, and Yang (2017). This level of pay means people are satisfied with their amount of salary that they should receive, the higher they get means more social and economic benefits Yao, Locke, and Jamal (2018) . Pay level satisfaction is one of the four dimensions of pay satisfaction Ren et al. (2017) . This pay satisfaction was measured by Cantril Ladder using 11-points Glatzer and Gulyas (2014) which was broadly known and used is employee outlook research Kulikowski (2018). 


\section{Mll Macrothink}

Journal of Management Research

ISSN 1941-899X

2019, Vol. 11, No. 3

According to Darus, Azizan, and Ahmad (2016), pay satisfaction is the fairly payment system which is significantly related to company commitment. The design of the pay system has four types of equity; internal equity, external equity, private equity and pay efficiency. Therefore, when employees are highly satisfied with their pay it will lead to raise organizational commitment. An early study shows that the intention for turnover will be reduced when the employees receive raises in their payment but not a raise in the pay level satisfaction Vandenberghe and Tremblay (2008). The study by Salleh and Memon (2015) suggested that the employee engagement is a mediator between pay satisfaction and intention turnover, and has positive results on the employee's behavior and attitude. In this research we will study the impact of pay level satisfaction on work engagement as a dependent variable.

\section{b) Company reputation}

Through the years company reputation has had the biggest attention in the research field Ginesti, Caldarelli, and Zampella (2018) and caught the academic and management interest Ali, Lynch, Melewar, and Jin (2015). Previous studies have focused on the study of corporate reputation as a general term for all types of companies. Fombrun, Gardberg, and Barnett (2000), define corporate reputation as "a cognitive representation of a company's actions and results that crystallizes the firm's ability to deliver valued outcomes to its stakeholders" (p. 87). Liu, North, and Li (2017), noted that the reputation of any institution is based on how others judge and evaluate it, and also the society's perception of the company's reliability, confidence in quality and how the stockholders see the firm as "worthy" Engizek and Yasin (2017). Previous studies assure that a positive reputation has several benefits such as dealing with external aspects, outstanding talented candidates and good relationships with stockholders Ginesti et al. (2018). Huang and Kang (2018) provided that companies with high reputations have an impact on the finance equity and activities, and that leads to low cost on equity investment. Corporate reputation has a huge impact on the company performance, thereby maximizing competitive advantages Pires and Trez (2018). This study attempts to examine the direct impact of corporate reputation on work engagement.

\section{c) Work engagement}

Work engagement is defined as a "positive, fulfilling, work-related state of mind that is characterized by vigor, dedication and absorption" Schaufeli, Salanova, González-Romá, and Bakker (2002). On other words employees are strongly connected to their work. Kahn (1990), points out that during role performance employees tend to express themselves in physical, cognitive, and emotional manners. Work engagement has been investigated and defined according to the attitudes and behaviors of employees. Karanika-Murray, Duncan, Pontes, and Griffiths (2015) linked work engagement to organization identification. Employees' behavior and attitude can be improved with engagement.

Engelbrecht, Heine, and Mahembe (2017) found that the trust and honor that the leaders highly provide their employees, also the fairly and respectable treated from them will lead the employees to become more agreeable and engaged in their work. The researcher found that 


\section{Macrothink Institute ${ }^{\mathrm{TM}}$}

the relationship between pay for performance and work engagement is from pay satisfaction and they play the part of not entirely mediated variables. Kulikowski (2018) Found that pay satisfaction is through the relationship between pay for performance and work engagement and they both don't have the fully mediated variable.

For the purpose of the present study we will study the work engagement as a dependent variable affected by pay level satisfaction and company reputation.

\section{Theoretical Framework}

The Work-engagement theory was established by Kahn (1990). He argued that the theory states that the perception of job situation influences employees' emotional responses which affect their work engagement. Work engagement contains two scopes: self-employment and self-expression. Self-employment can be described as the personal drives and work behaviors. Also, self-expression relies on expressing the behavior. CHEN, Zhang, and Vogel (2011) said that in their experiential study it was found that work engagement affected job performance, job attitude and job effort. Furthermore, Kulikowski (2018) established that the relationship between pay for performance and work engagement is from pay satisfaction.

\section{Research Model}

This study will be built on the follow model:

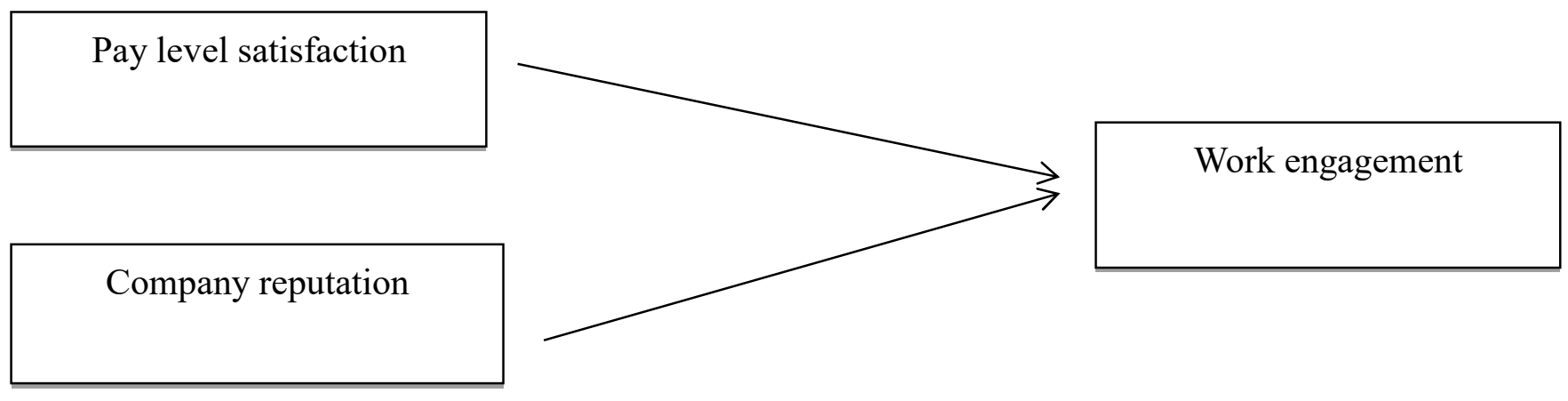

\section{Research Hypotheses}

H1: Pay level satisfaction has a significant statistical impact on work engagement.

$\mathrm{H} 2$ : Company reputation has a significant statistical impact on work engagement.

\section{Research Methodology}

\section{Data Collection Method and Sampling Framework}

This study aims to examine in a quantitative method the impact of pay level satisfaction and company reputation on work engagement. The sample covers male and female randomly selected from different ages who graduated between 2010 and 2017 and are working in both public and privet universities in Saudi Arabia. Respondents were informed of the purpose of the study, and their responses will be confidential and will be used for scientific reasons only. The survey was internet-based and 83 participants responded but 11 were excluded because they were incompatible with the sample. 


\section{Data Collection Instrument}

The questionnaire used 5-points Likert scale ranging from (Strongly Disagree) to (Strongly Agree). There were three subscales; a Pay level satisfaction scale, a company reputation scale, and a work engagement scale. The first subscale included 4 items that were adopted from Tang et al. (2006) . The second subscale was Company reputation which was obtained from Terblanche (2014). Finally, the third subscale was work engagement which was adopted from Ho Kim, Park, and Kwon (2017). The questionnaire was mainly established in English then translated to Arabic, after that translated back to English to assure the compatibility of the translation. Additionally, demographic variables were stated at the beginning of the questionnaire

\section{Data Analysis}

The three subscales of the questionnaire used in the current study were analyzed via the Statistical Package for the Social Sciences (SPSS) software. In order to test the reliability of the questionnaire, the instrument used in the study, internal consistency was examined and as illustrated in Table 1, the reliability coefficient was very high (.939).

Table 1. Coefficient alpha (Cronbach) for reliability of questionnaire

\begin{tabular}{lll}
\hline $\begin{array}{l}\text { Cronbach's } \\
\text { Alpha }\end{array}$ & $\begin{array}{l}\text { Cronbach's Alpha Based } \\
\text { on Standardized Items }\end{array}$ & N of Items \\
\hline .938 & .939 & 18 \\
\hline
\end{tabular}

\section{Results and Findings}

In Table 2, below a description of the participants' gender, age, education level, and university sector (i.e., private or public) are illustrated. The participants were from both genders $44.4 \%$ were males while $55.6 \%$ were female. Their ages ranged between, 24 to $30+$ from both genders. Their education level varied, but the majority of the participants both male and female participants were BA and MA level. Another interesting finding was that the majority of the participants were from the public sector. 
Table 2. Descriptive Analysis

\begin{tabular}{|c|c|c|c|}
\hline \multicolumn{4}{|c|}{ Gender } \\
\hline & & Frequency & Percent \\
\hline \multirow[t]{3}{*}{ Valid } & Male & 32 & 44.4 \\
\hline & Female & 40 & 55.6 \\
\hline & Total & 72 & 100 \\
\hline \multicolumn{4}{|l|}{ Age } \\
\hline \multirow[t]{4}{*}{ Valid } & $24-26$ & 4 & 5.6 \\
\hline & $27-29$ & 27 & 37.5 \\
\hline & $30+$ & 41 & 56.9 \\
\hline & Total & 72 & 100 \\
\hline \multicolumn{4}{|c|}{ Education } \\
\hline \multirow[t]{6}{*}{ Valid } & Below Secondary & 1 & 1.4 \\
\hline & Diploma & 2 & 2.8 \\
\hline & BA & 36 & 50.0 \\
\hline & MA & 28 & 38.9 \\
\hline & $\mathrm{PhD}$ & 5 & 6.9 \\
\hline & Total & 72 & 100 \\
\hline \multicolumn{4}{|c|}{ University } \\
\hline \multirow[t]{3}{*}{ Valid } & Private & 7 & 9.7 \\
\hline & Public & 65 & 90.3 \\
\hline & Total & 72 & 100 \\
\hline
\end{tabular}

In order to achieve the objectives of the study a Pearson correlation test was conducted. As illustrated in Table 3 below the results were statistical. Based on the results below, Pay Level Satisfaction and Work Engagement have a statistically significant linear relationship $(p<.011)$. Pay Level Satisfaction and Work Engagement are positively correlated, and the direction of the relationship is positive, meaning that these variables tend to increase together which means that a greater Company Reputation is associated with greater Work Engagement. The magnitude, or strength, of the association is low to moderate $(r=.298)$. 
Table 3. Pay Level Satisfaction and Work Engagement Correlations

\begin{tabular}{|c|c|c|c|}
\hline & & Pay Level Satisfaction & Work Engagement \\
\hline \multirow{3}{*}{$\begin{array}{l}\text { Pay Leve } \\
\text { Satisfaction }\end{array}$} & Pearson Correlation & 1 & .298 \\
\hline & Sig. (2-tailed) & & .011 \\
\hline & $\mathrm{N}$ & 72 & 72 \\
\hline \multirow{3}{*}{$\begin{array}{l}\text { Work } \\
\text { Engagement }\end{array}$} & Pearson Correlation & .298 & 1 \\
\hline & Sig. (2-tailed) & .011 & \\
\hline & $\mathrm{N}$ & 72 & 72 \\
\hline
\end{tabular}

As illustrated in Table 4 below, the results indicated that the Company Reputation and Work Engagement have a statistically significant linear relationship $(p<.001)$. Company Reputation and Work Engagement are positively correlated, and the direction of the relationship is positive, meaning that these variables tend to increase together which means that a greater Company Reputation is associated with greater Work Engagement. The magnitude, or strength, of the association is moderate $(r=.678)$.

Table 4. Company Reputation and Work Engagement Correlations

\begin{tabular}{llll}
\hline & & Company Reputation & Work Engagement \\
\hline $\begin{array}{llll}\text { Company } \\
\text { Reputation }\end{array}$ & Pearson Correlation & 1 & .678 \\
\cline { 2 - 4 } & Sig. (2-tailed) & .000 \\
\cline { 2 - 4 } & $\mathrm{N}$ & 72 & 72 \\
\hline Work & Pearson Correlation & .678 & 1 \\
\cline { 2 - 4 } & Sig. (2-tailed) & .000 & 72 \\
\cline { 2 - 4 } & $\mathrm{N}$ & 72 & 72 \\
\hline
\end{tabular}

The current study had two hypotheses which were both statistical and supported by the results as indicated in Table 5. The first hypothesis was that there is a correlation between Payment Level Satisfaction and Work Engagement. The second hypothesis was that there is a correlation between Company Reputation and Work Engagement. 
Table 5. The study's Hypotheses

\begin{tabular}{llll}
\hline Hypotheses & Type & Sig & Result \\
\hline H1 & $\begin{array}{l}\text { There is a correlation between Payment Level } \\
\text { Satisfaction and Work Engagement }\end{array}$ & Supported \\
\hline $\mathrm{H} 2$ & $\begin{array}{l}\text { There is a correlation between Company } \\
\text { Reputation and Work Engagement }\end{array}$ & .000 & Supported \\
\hline
\end{tabular}

\section{Discussion and Conclusion}

The main reason of conducting the current study was to explore the impact of both pay level satisfaction and company reputation on work engagement. The findings of the study indicated that there was a statistical impact of these two independent variables on work engagement which is the dependent variable. The correlation between company reputation and work engagement was more than the correlation between Pay level satisfaction and work engagement. These finding have important implications such as giving more attention to the institutions reputation. Therefore, universities should focus on pay level satisfaction and their reputation to insure work engagement. The findings of the current study are in line with findings of (Kulikowski, 2018) who found that the relationship between pay level and work engagement plays an important role in the working environment.

\section{Limitation}

This study is one of the first studies conducted in Saudi Arabia to examine the relationship between pay level satisfaction, company reputation and work engagement. The researcher faced a few limitations since the study was limited to a sample that graduated between 2010 and 2017. As a result only a limited amount of employees were capable of participating in the study. Finally, the number of public universities in Saudi Arabia is 25 and 8 privet distributed geographically between the regions of the kingdom that made it difficult to reach all participants although the instrument was an online one.

\section{Future study}

The findings of this research indicated that there are future opportunities for future studies in the field for the goal of improving work engagement. The researcher recommends broadening the year of graduation in order to cater for a bigger number of participants. Also, it is suggested that future research can examine other factors that affect work engagement, such as job satisfaction and performance. Future studies may examine all aspects of job satisfaction rather than focus on pay level satisfaction.

\section{Acknowledgment}

The authors extend their appreciation to the Deanship of Scientific Research at King Saud University for financing the study. 


\section{References}

Aboshaiqah, A. (2016). Strategies to address the nursing shortage in Saudi Arabia. International nursing review, 63(3), 499-506. https://doi.org/10.1111/inr.12271

Aboshaiqah, A. E., Hamadi, H. Y., Salem, O. A., \& Zakari, N. M. (2016). The work engagement of nurses in multiple hospital sectors in Saudi Arabia: a comparative study. Journal of nursing management, 24(4), 540-548. https://doi.org/10.1111/jonm. 12356

Alharbi, J., Wilson, R., Woods, C., \& Usher, K. (2016). The factors influencing burnout and job satisfaction among critical care nurses: a study of Saudi critical care nurses. Journal of nursing management, 24(6), 708-717. https://doi.org/10.1111/jonm.12386

Ali, R., Lynch, R., Melewar, T., \& Jin, Z. (2015). The moderating influences on the relationship of corporate reputation with its antecedents and consequences: A meta-analytic review. Journal of Business Research, 68(5), 1105-1117. https://doi.org/10.1016/j.jbusres.2014.10.013

Banafea, W., \& Ibnrubbian, A. (2018). Assessment of economic diversification in Saudi Arabia through nine development plans. OPEC Energy Review, 42(1), 42-54. https://doi.org/10.1111/opec.12116

Burton, E. (2016). Business and Entrepreneurship in Saudi Arabia: Opportunities for Partnering and Investing in Emerging Businesses: John Wiley \& Sons. https://doi.org/10.1002/9781118949146

CHEN, Z. J., Zhang, X., \& Vogel, D. (2011). Exploring the Underlying Processes Between Conflict and Knowledge Sharing: A Work - Engagement Perspective 1. Journal of applied social psychology, 41(5), 1005-1033. https://doi.org/10.1111/j.1559-1816.2011.00745.x

Darus, A., Azizan, F. L., \& Ahmad, F. (2016). WORK STRESS, PAY SATISFACTION, PSYCHOLOGICAL EMPOWERMENT AND ORGANISATIONAL COMMITMENT AMONG ACADEMIC STAFF. IJMS, 23(1), 51-72.

Engelbrecht, A. S., Heine, G., \& Mahembe, B. (2017). Integrity, ethical leadership, trust and work engagement. Leadership \& Organization Development Journal, 38(3), 368-379. https://doi.org/10.1108/LODJ-11-2015-0237

Engizek, N., \& Yasin, B. (2017). How CSR and overall service quality lead to affective commitment: mediating role of company reputation. Social Responsibility Journal, 13(1), 111-125. https://doi.org/10.1108/SRJ-09-2015-0135

Fombrun, C. J., Gardberg, N. A., \& Barnett, M. L. (2000). Opportunity platforms and safety nets: Corporate citizenship and reputational risk. Business and society review, 105(1), 85-106. https://doi.org/10.1111/0045-3609.00066

Ginesti, G., Caldarelli, A., \& Zampella, A. (2018). Exploring the impact of intellectual capital on company reputation and performance. Journal of Intellectual Capital, 19(5), 915-934. https://doi.org/10.1108/JIC-01-2018-0012 
Glatzer, W., \& Gulyas, J. (2014). Cantril self-anchoring striving scale. In Encyclopedia of quality of life and well-being research (pp. 509-511): Springer. https://doi.org/10.1007/978-94-007-0753-5_259

Ho Kim, W., Park, J. G., \& Kwon, B. (2017). Work engagement in South Korea: Validation of the Korean version 9-item Utrecht work engagement scale. Psychological Reports, 120(3), 561-578. https://doi.org/10.1177/0033294117697085

Huang, X., \& Kang, F. (2018). Company reputation and auditor choice: evidence from Fortune 1000 companies. Accounting Research Journal(just-accepted), 00-00. https://doi.org/10.1108/ARJ-06-2015-0079

Kahn, W. A. (1990). Psychological conditions of personal engagement and disengagement at work. Academy of management journal, 33(4), 692-724. https://doi.org/10.5465/256287

Karanika-Murray, M., Duncan, N., Pontes, H. M., \& Griffiths, M. D. (2015). Organizational identification, work engagement, and job satisfaction. Journal of Managerial Psychology, 30(8), 1019-1033. https://doi.org/10.1108/JMP-11-2013-0359

Kulikowski, K. (2018). The model of relationships between pay for individual performance and work engagement. Career Development International, 23(4), 427-443. https://doi.org/10.1108/CDI-10-2017-0181

Liu, J. H., North, M., \& Li, C. (2017). Relationship building through reputation and tribalism on companies' Facebook pages: A uses and gratifications approach. Internet Research, 27(5), 1149-1169. https://doi.org/10.1108/IntR-03-2016-0078

Pires, V., \& Trez, G. (2018). Corporate reputation: A discussion on construct definition and measurement and its relation to performance. Revista de Gestão, 25(1), 47-64. https://doi.org/10.1108/REGE-11-2017-005

Ren, T., Fang, R., \& Yang, Z. (2017). The impact of pay-for-performance perception and pay level satisfaction on employee work attitudes and extra-role behaviors: An investigation of moderating effects. Journal of Chinese Human Resource Management, 8(2), 94-113. https://doi.org/10.1108/JCHRM-06-2015-0012

Salleh, R., \& Memon, M. A. (2015). A review on the effects of pay satisfaction on employee engagement and turnover: a proposed mediating framework. International Business Management, 9(3), 344-348.

Schaufeli, W. B., Salanova, M., González-Romá, V., \& Bakker, A. B. (2002). The measurement of engagement and burnout: A two sample confirmatory factor analytic approach. Journal of Happiness studies, $3(1), \quad 71-92$. https://doi.org/10.1023/A:1015630930326

Tang, T. L.-P., Sutarso, T., Akande, A., Allen, M. W., Alzubaidi, A. S., Ansari, M. A., . . . Charles-Pauvers, B. (2006). The love of money and pay level satisfaction: Measurement and functional equivalence in 29 geopolitical entities around the world. Management and Organization Review, 2(3), 423-452. https://doi.org/10.1111/j.1740-8784.2006.00051.x 


\section{Macrothink}

Journal of Management Research

ISSN 1941-899X 2019, Vol. 11, No. 3

Terblanche, N. S. (2014). Validation of the customer-based corporate reputation scale in a retail context. International journal of Market research, 56(5), 655-671. https://doi.org/10.2501/IJMR-2014-044

Vandenberghe, C., \& Tremblay, M. (2008). The role of pay satisfaction and organizational commitment in turnover intentions: A two-sample study. Journal of Business and psychology, 22(3), 275-286. https://doi.org/10.1007/s10869-008-9063-3

Varshney, D., \& Varshney, N. K. (2017). The effect of resilience on performance and job satisfaction among construction managers in Saudi Arabia. Global Business and Organizational Excellence, 36(5), 36-45. https://doi.org/10.1002/joe.21799

Yao, Y. H., Locke, E. A., \& Jamal, M. (2018). On a combined theory of pay level satisfaction. Journal of Organizational Behavior, 39(4), 448-461. https://doi.org/10.1002/job.2243 